\title{
Lipid Composition, Fatty Acids and Sterols in the Seaweeds Ulva armoricana, and Solieria chordalis from Brittany (France): An Analysis from Nutritional, Chemotaxonomic, and Antiproliferative Activity Perspectives
}

\author{
Melha Kendel ${ }^{1}$, Gaëtane Wielgosz-Collin ${ }^{2}$, Samuel Bertrand ${ }^{2}$, Christos Roussakis ${ }^{3}$, \\ Nathalie Bourgougnon ${ }^{1}$ and Gilles Bedoux ${ }^{1, *}$ \\ 1 University of South Brittany, EA 3884, LBCM, IUEM, F-56000 Vannes, France; \\ E-Mails: melha.kendel@gmail.com (M.K.); nathalie.bourgougnon@univ-ubs.fr (N.B.) \\ 2 Faculté des Sciences Pharmaceutiques et Biologiques, LUNAM, Université de Nantes, Groupe \\ Mer-Molécules-Santé MMS, EA 2160, Institut Universitaire Mer et Littoral FR3473 \\ CNRS, 9 Rue Bias, BP 53508, F-44035 Nantes Cedex 1, France; \\ E-Mails: wielgosz-collin@univ-nantes.fr (G.W.-C.); samuel.bertrand@univ-nantes.fr (S.B.) \\ 3 Faculté des Sciences Pharmaceutiques et Biologiques, LUNAM Université, Université de Nantes, \\ IICIMED/ERATU-EA 1155 Cancer du Poumon et Cibles Moléculaires, 1 Rue Gaston Veil, \\ BP 53508, F-44035 Nantes Cedex 01, France; E-Mail: christos.roussakis@univ-nantes.fr \\ * Author to whom correspondence should be addressed; E-Mail: gilles.bedoux@univ-ubs.fr; \\ Tel.: +33-297-017-157; Fax: +33-297-017-071.
}

Academic Editor: Orazio Taglialatela-Scafati

Received: 30 May 2015 / Accepted: 14 August 2015 / Published: 2 September 2015

\begin{abstract}
Lipids from the proliferative macroalgae Ulva armoricana (Chlorophyta) and Solieria chordalis (Rhodophyta) from Brittany, France, were investigated. The total content of lipids was $2.6 \%$ and $3.0 \%$ dry weight for $U$. armoricana and S. chordalis, respectively. The main fractions of $S$. chordalis were neutral lipids (37\%) and glycolipids (38\%), whereas $U$. armoricana contained mostly neutral lipids (55\%). Polyunsaturated fatty acids (PUFA) represented $29 \%$ and $15 \%$ of the total lipids in U. armoricana and S. chordalis, respectively. In both studied algae, the phospholipids were composed of PUFA for $18 \%$. In addition, PUFA were shown to represent $9 \%$ and $4.5 \%$ of glycolipids in U. armoricana and $S$. chordalis, respectively. The essential PUFA were $16: 4 n-3,18: 4 n-3,18: 2 n-3,18: 2 n-6$, and $22: 6 n-3$ in $U$. armoricana, and 20:4n-6 and 20:5n-3 in S. chordalis. It is important to notice that six 2-hydroxy-, three 3-hydroxy-, and two monounsaturated hydroxy fatty acids were also
\end{abstract}


identified and may provide a chemotaxonomic basis for algae. These seaweeds contained interesting compounds such as squalene, $\alpha$-tocopherol, cholest-4-en-3-one and phytosterols. The antiproliferative effect was evaluated in vitro on human non-small-cell bronchopulmonary carcinoma line (NSCLC-N6) with an IC50 of $23 \mu \mathrm{g} / \mathrm{mL}$ for monogalactosyldiacylglycerols isolated from $S$. chordalis and $24 \mu \mathrm{g} / \mathrm{mL}$ for digalactosyldiacylglycerols from $U$. armoricana. These results confirm the potentialities of valorization of these two species in the fields of health, nutrition and chemotaxonomy.

Keywords: Ulva armoricana; Solieria chordalis; fatty acids; sterols; phospholipids; glycolipids; polyunsaturated fatty acids; hydroxy fatty acids; chemotaxonomy; human lung cancer

\section{Introduction}

Seaweeds are known for their richness in nutritionally beneficial components and contain bioactive compounds such as proteins, carbohydrates, antioxidants, minerals, dietary fibers, vitamins and polyunsaturated fatty acids (PUFAs) [1].

In recent years, lipid composition in marine algae has raised considerable interest due to their high content of PUFAs, specifically $\alpha$-linolenic (18:3n-3), octadecatetraenoic (18:4n-3), arachidonic (20:4n-6), and eicosapentaenoic acids (20:5n-3) [2]. This class of acids was considered as essential nutritional components in humans and animals [3]. For example, they play an important role in the prevention of cardiovascular diseases, osteoarthritis, diabetes, and it possesses antimicrobial, antiviral, anti-inflammatory and antitumoral properties $[2,3]$.

Furthermore, studies dealing with fatty acids (FA) of seaweeds are also interesting for the usefulness of FA as potential chemotaxonomic biomarkers. Their lipid profiles could assist the assignment of algal taxonomic position and provide signature profiles for use in organic geochemistry and food studies [4]. Such biochemical analysis may also be useful to study the abundance and ecology of these species in the marine environments.

An attractive approach to find sources of marine lipids, could be the exploitation of coastal proliferative seaweeds species especially if they contain interesting substances. This is the case for Solieria chordalis (Rhodophyta) and for Ulva armoricana (Chlorophyta), which are proliferative species found in Brittany (North West of France).

Thus, the present study explores the lipid composition of $S$. chordalis for the first time and of $U$. armoricana for extending the knowledge on its lipid composition where little is known about FA composition of individual lipid classes. The aim is the determination of the potential value of lipid composition (total lipid, glycolipid-GL, phospholipids-PL, sterol and unsaponifiable fraction) of these proliferative species, which may constitute a nutritional database for chemotaxonomy and anti-proliferative activity perspectives.

So, for these two species, the present study was designed to clarify the content of lipid and glycolipid (GL) classes, and the FA composition from total lipids, phospholipids (PL), GL and compounds of unsaponifiable fraction. In addition, the GL fractions were evaluated for their anti-proliferative activity against human cancer cell lines (non-small cell lung cancer-NSCLC-N6). This present study particularly 
focuses on lung cancer and to the best of our knowledge for the first time for these species, lung cancer being the leading cause of cancer-related mortality in both men and women in the world.

\section{Results and Discussion}

\subsection{Lipid Contents and Lipid Classes Distribution}

The specimens of Chlorophyta (Ulva armoricana) and Rhodophyta (Solieria chordalis) used in the present investigation were based on their wide distribution and abundance in Brittany (North West of France). The total lipid (TL) contents and the lipid class distribution are reported in Table 1.

Table 1. Total lipid contents (\% dry weight) and lipid class distribution ( $\%$ total lipids) of U. armoricana and $S$. chordalis.

\begin{tabular}{ccc}
\hline & U. armoricana $(\%)$ & S. chordalis $(\%)$ \\
\hline Water content fresh algae & $92.00 \pm 1.25$ & $90.05 \pm 0.70$ \\
Total lipids & $2.62 \pm 0.04$ & $2.96 \pm 0.04$ \\
Neutral lipids & $55.60 \pm 0.05$ & $37.70 \pm 0.07$ \\
Glycolipids & $29.10 \pm 0.10$ & $38.50 \pm 0.02$ \\
Phospholipids & $15.30 \pm 0.10$ & $23.70 \pm 0.09$ \\
\hline
\end{tabular}

Values are the mean of three replicates (mean $(\%$ dw $) \pm$ s.d.); s.d., standard deviation.

The TL content of $U$. armoricana and $S$. chordalis was established at $2.62 \% \pm 0.04 \%$ dry weight (dw) and $2.96 \% \pm 0.04 \%(\mathrm{dw})$, respectively. These contents are in agreement with the literature $[5,6]$. Table 2 shows the TL contents previously found in various $U$. armoricana ranging from $0.2 \%$ to $7.9 \% \mathrm{dw}$ and for Solieria sp. whose levels vary from $0.4 \%$ to $2.8 \%$. The values determined in this study are higher than those reported for different species of the same genus, as shown in Table 2. Nevertheless, it is interesting to note that brown seaweeds generally contain higher TL levels [5]. Furthermore, the TL contents of $U$. armoricana and $S$. chordalis are lower compared to earth vegetables, such as soy or sunflower [6]. 
Table 2. Total lipid contents of various algal Ulva and Solieria species.

\begin{tabular}{|c|c|c|c|c|c|}
\hline Phylum & Algal Species & Location & Date & $\begin{array}{c}\text { Reported } \\
\text { Levels (\%) }\end{array}$ & References \\
\hline \multirow{5}{*}{ Chlorophyta } & \multirow[b]{2}{*}{ Ulva sp. } & Beach in Plestin-les-Grèves, France & June 2012 & $0.6 \% \mathrm{dw}$ & [7] \\
\hline & & $\begin{array}{c}\text { north-east part of the Black Sea } \\
\text { (Feodosiya and Karadag Bays, Crimea) }\end{array}$ & July 1987 & $0.2 \% \mathrm{dw}$ & [8] \\
\hline & \multirow{3}{*}{ U. lactuca } & $\begin{array}{c}\text { Coast of Abu Qir Bay near Boughaz } \\
\text { El-Maadya (Egypt) }\end{array}$ & $\begin{array}{l}\text { April, August and } \\
\text { October } 2010\end{array}$ & $4.0 \% \mathrm{dw}$ & [9] \\
\hline & & Buleji beach of Karachi coast & $\begin{array}{l}\text { Different seasons at } \\
\text { low tide }\end{array}$ & $1.2 \% \mathrm{dw}$ & {$[10]$} \\
\hline & & $\begin{array}{c}\text { Littoral between the area of Téboulba } \\
\text { and Sayada (Monastir-Tunisia) }\end{array}$ & July 2007 & $7.9 \% \mathrm{dw}$ & {$[11]$} \\
\hline \multirow{12}{*}{ Chlorophyta } & \multirow{6}{*}{ U. lactuca } & Indian Sundarbans & $\begin{array}{l}\text { September } 2007- \\
\text { June } 2008\end{array}$ & $0.3 \%-1.0 \% \mathrm{dw}$ & {$[12]$} \\
\hline & & Bohai Sea near Weihai (China) & August & $1.2 \% \mathrm{fw}$ & [13] \\
\hline & & Bodega Bay, California & November 1995 & $3.1 \% \mathrm{dw}$ & {$[14]$} \\
\hline & & Coast of Norway & May and June 2012 & $2.6 \% \mathrm{dw}$ & {$[15]$} \\
\hline & & Coast of the Persian Gulf (Iran) & - & $3.6 \% \mathrm{dw}$ & {$[16]$} \\
\hline & & Ria de Aveiro & October 2012 & $0.3 \% \mathrm{dw}$ & {$[17]$} \\
\hline & \multirow[t]{2}{*}{$U$. rigida } & $\begin{array}{c}\text { north-east part of the Black Sea } \\
\text { (Feodosiya and Karadag Bays, Crimea) }\end{array}$ & July 1987 & $0.3 \% \mathrm{dw}$ & [8] \\
\hline & & Varvara, Bulgaria & October 2011 & $0.8 \% \mathrm{fw}$ & {$[18]$} \\
\hline & U. fenestrata & $\begin{array}{c}\text { Pacific Ocean in the Northern part } \\
\text { of Canada }\end{array}$ & - & $0.5 \%$ la & {$[19]$} \\
\hline & U. pertusa & Bohai Sea near Weihai (China) & August & $0.9 \% \mathrm{fw}$ & [13] \\
\hline & $\begin{array}{c}\text { U. lactuca } \\
\text { U. fasciata } \\
\text { U. taeniata } \\
\text { U. pertusa } \\
\text { U. reticulata } \\
\text { U. beytensis } \\
\text { U. compressa } \\
\text { U. rIgida } \\
\text { U. linza } \\
\text { U. flexuosa } \\
\text { U. erecta } \\
\text { U. prolifera }\end{array}$ & Gujarat coast, India & March-October 2011 & $0.7 \%-2.0 \%$ fw & {$[20]$} \\
\hline & U. linza & Abu Qir Bay, Egypt & $\begin{array}{l}\text { Spring, } \\
\text { summer, } \\
\text { autumn }\end{array}$ & $\begin{array}{l}4.1 \% \mathrm{dw}, \\
3.8 \% \mathrm{dw}, \\
3.2 \% \mathrm{dw}\end{array}$ & {$[21]$} \\
\hline \multirow{4}{*}{ Rhodophyta } & S. chordalis & $\begin{array}{l}\text { Littoral zone of the Saint Gildas de } \\
\text { Rhuys, France }\end{array}$ & March 2012 & $0.9 \% \mathrm{dw}$ & [7] \\
\hline & \multirow{3}{*}{ S. robusta } & Gujarat coast, India & March-October 2011 & $\begin{array}{c}0.4 \%-1.0 \% \text { fw } \\
0.9 \% \text { fw }\end{array}$ & {$[20]$} \\
\hline & & Buleji beach of Karachi coast & $\begin{array}{l}\text { Different seasons at } \\
\text { low tide }\end{array}$ & $2.8 \% \mathrm{dw}$ & {$[10]$} \\
\hline & & Sea of South China & - & $0.3 \%$ la & [19] \\
\hline
\end{tabular}


These variations could be related to taxonomic entity, seasonality of sampling, location and macroalgae growth conditions [22], in addition to extraction processing and solvent polarity [23]. Sánchez-Machado et al. reported that, as the temperature increased, the lipid level decreased and remained almost stable until the end of the growing season [24]. In comparison to Grateloupia turuturu (Halymeniaceae), the lipid contents are lower, G. turuturu TL content being 3\%-4\% dw [25]. Each of the TL extracts was fractionated into three fractions corresponding to lipid classes (Table 1): neutral lipids (NL-storage lipids), glycolipids (GL) and phospholipids (PL-structural lipids). For S. chordalis, the major lipid classes corresponded to NL and GL, accounting for $38 \%$ each, followed by PL (24\%). In the case of U. armoricana, the main lipid class was NL with 56\%, followed by GL (29\%) and by PL (15\%).

\subsection{Lipid Composition}

\subsubsection{Neutral Lipid and Sterol Composition}

$U$. armoricana and S. chordalis were examined for their hydrocarbons and sterols present in unsaponifiable fractions. The analyses were carried out by gas chromatography coupled to mass spectrometry (GC-MS) and observed compositions are given in Table 3.

Table 3. Composition (\%) of the unsaponifiable fractions of $U$. armoricana and $S$. chordalis.

\begin{tabular}{ccc}
\hline & $\begin{array}{c}\text { U. armoricana (\%) } \\
\text { (21\% Total Lipids) }\end{array}$ & $\begin{array}{c}\text { S. chordalis (\%) } \\
\text { (10\% Total Lipids) }\end{array}$ \\
\hline & Hydrocarbons & \\
\hline Hydrocarbons & $4.3 \pm 0.1$ & $5.7 \pm 0.2$ \\
Squalene & $2.7 \pm 0.1$ & $4.5 \pm 0.1$ \\
Total hydrocarbons & $\mathbf{7 . 0} \pm \mathbf{0 . 1}$ & $\mathbf{1 0 . 2} \pm \mathbf{0 . 1}$ \\
\hline \multicolumn{3}{c}{ Sterols } \\
\hline 22(E)-Dehydrocholesterol & $1.0 \pm 0.1$ & $1.3 \pm 0.1$ \\
Cholesterol & $35.2 \pm 0.3$ & $42.6 \pm 0.2$ \\
Campesterol & $1.3 \pm 0.1$ & $1.7 \pm 0.1$ \\
Brassicasterol & $3.0 \pm 0.2$ & $2.1 \pm 0.1$ \\
22-Dehydrolathosterol & $0.8 \pm 0.1$ & $1.0 \pm 0.1$ \\
Fucosterol & $1.4 \pm 0.1$ & $2.3 \pm 0.1$ \\
Isofucosterol & $25.0 \pm 0.2$ & $\mathrm{nd}{ }^{\mathrm{a}}$ \\
Cholest-4-en-3-one & $0.8 \pm 0.1$ & $2.0 \pm 0.1$ \\
Total sterols & $\mathbf{6 8 . 5} \pm \mathbf{0 . 1}$ & $\mathbf{5 3 . 0} \pm \mathbf{0 . 1}$ \\
\hline \multicolumn{3}{c}{ Other compounds } \\
\hline a-Tocopherol & $5.5 \pm 0.1$ & $3.1 \pm 0.1$ \\
Phytol & $19.0 \pm 0.1$ & $33.7 \pm 0.3$ \\
\hline
\end{tabular}

Values are the mean of three replicates (mean $(\% \mathrm{dw}) \pm$ s.d.); s.d., standard deviation; ${ }^{\mathrm{a}}$ nd, not detected.

Hydrocarbons represented $7 \%$ of the unsaponifiable fraction for $U$. armoricana, among which squalene corresponded to $2.7 \%$ (Table 3 ). It is interesting to note that a rich squalene diet enhances anti-tumor activity of some chemotherapeutic agents by increasing immune system efficiency and by lowering blood cholesterol content [26]. Moreover, there is some evidence that squalene reduces colon cancer and skin cancer; this activity likely being related to its antioxidant status [27]. Therefore, squalene may be 
beneficial in preventive therapy and integrative medicine. Additionally, $\alpha$-tocopherol represented 5.5\% of the unsaponifiable fraction from $U$. armoricana (Table 3), and is an important natural antioxydant [28].

Moreover, it also contained 19\% phytol (Table 3). This particular compound is usually used as a precursor for the industrial synthesis of vitamins $\mathrm{E}$ and $\mathrm{K}[29,30]$.

The major constituent of the unsaponifiable fraction from U. armoricana was cholesterol (35\%), which is one of the main sterols present in seaweeds. Its content in green and brown algae varies from $2 \%$ to $76 \%$ of total sterol. In red algae, its content is lower; however, it is still among the major components of the sterol fraction [31]. Some green algae, such as Ulva and Chaetomorpha, contain cholesterol or 28-isofucosterol as their principal sterol [32].

Cholest-4-en-3-one was also detected as a minor component for $U$. armoricana $(0.8 \%$, Table 3$)$. This compound is a key intermediate in steroid chemistry, which is known as a cholesterol derivative occurring in both plant and animal tissues [33]. It may result from the biosynthesis or the autoxidation of cholesterol. Cholest-4-en-3-one, known as an intestinal catabolite of cholesterol, has an anti-obesity effect on animals [34].

Finally, the unsaponifiable fraction of $U$. armoricana also contained other phytosterols. They corresponded to campesterol, brassicasterol, isofucosterol, which are known to exhibit cholesterol-lowering effects by decreasing intestinal cholesterol absorption [35]. Furthermore, the activity of phytosterols on cardiovascular diseases and their potent anti-inflammatory properties have been reported [35]. For Humans, all phytosterols come from dietary sources, as Humans cannot de novo synthesize phytosterols.

Aknin et al. have investigated sterol composition of three Chlorophyceae orders and showed that sterol composition offers distinguishing features for the chemotaxonomic classification of these algae [36]. Isofucosterol is typical for Ulotrichales and particularly the Ulvaceae family. Nobuo et al. have also found that the sterol content in marine Chlorophyta is similar to higher plants [37].

Regarding S. chordalis, hydrocarbons represented $10.2 \%$ of the unsaponifiable fraction, among which squalene corresponded to $4.5 \%$. Furthermore, $\alpha$-tocopherol and phytol were also detected and represented $3.1 \%$ and $34 \%$ of the unsaponifiable fraction, respectively. The main component of the unsaponifiable fraction was cholesterol (43\%). Other minor sterols were detected such as cholest-4-en-3-one, but no isofucosterol was detected (Table 3).

Our results about sterols composition of $S$. chordalis (Gigartinales) showed differences with the results of Nasir et al. who identified 22-dehydrocholesterol, cholesterol and stigmasterol from Gracilaria salicornia (Gigartinales), and 22-dehydrocholesterol, cholesterol, cholesterol oleate, and (22E)-cholesta-5,22-dien-3ß-ol-7-one from Hypnea flagelliformis (Gigartinales) [38].

\subsubsection{Fatty Acid Composition of Total Lipids}

All fatty acids (FAs) of the TL were converted into the fatty acid methyl esters (FAMEs) by transmethylation with methanolic hydrogen chloride. The FAs were identified as FAME by comparing their equivalent chain lengths (ECLs) values with those previously described or by using commercial mixtures. The ECLs of the FAMEs were determined by expressing their elution positions relative to those of known straight-chain saturated FAMEs.

FAMEs were converted to $N$-acyl pyrrolidides (NAPs) in order to locate double bonds and branching [28]. The FA composition of TL is given in Table 4. 
Table 4. Fatty acid (\% of the total FAs mixture) of U. armoricana and $S$. chordalis.

\begin{tabular}{|c|c|c|c|}
\hline Fatty Acid (FAs) ${ }^{a}$ & $\mathbf{E C L}^{\mathbf{c}}$ & U. armoricana $(\%)$ & S. chordalis $(\%)$ \\
\hline \multicolumn{4}{|c|}{ Saturated fatty acids (SFAs) } \\
\hline $14: 0$ & 14.00 & $0.6 \pm 0.2$ & $2.6 \pm 0.2$ \\
\hline $15: 0$ & 15.00 & $0.4 \pm 0.1$ & $1.4 \pm 0.1$ \\
\hline $16: 0$ & 16.00 & $42.0 \pm 0.2$ & $45.0 \pm 0.2$ \\
\hline 18:0 & 18.00 & $1.0 \pm 0.1$ & $9.9 \pm 0.1$ \\
\hline $22: 0$ & 22.00 & $2.3 \pm 0.1$ & $\mathrm{nd}^{\mathrm{b}}$ \\
\hline 24:0 & 24.00 & $0.2 \pm 0.1$ & $\mathrm{nd}^{\mathrm{b}}$ \\
\hline Total SFAs & & $46.5 \pm 0.1$ & $58.9 \pm 0.1$ \\
\hline \multicolumn{4}{|c|}{ Monounsaturated fatty acids (MUFAs) } \\
\hline $14: 1$ & 13.63 & $0.4 \pm 0.1$ & $\mathrm{nd}^{\mathrm{b}}$ \\
\hline $15: 1$ & 14.57 & $\mathrm{nd}^{\mathrm{b}}$ & $0.2 \pm 0.1$ \\
\hline $16: 1 n-9$ & 15.79 & $2.7 \pm 0.1$ & $\mathrm{nd}^{\mathrm{b}}$ \\
\hline $16: 1 n-7$ & 15.94 & $1.9 \pm 0.1$ & $\mathrm{nd}^{\mathrm{b}}$ \\
\hline $16: 1$ & 15.76 & $\mathrm{nd}^{\mathrm{b}}$ & $0.2 \pm 0.1$ \\
\hline $17: 1 n-7$ & 16.77 & $\mathrm{nd}^{\mathrm{b}}$ & $18.5 \pm 0.1$ \\
\hline $18: 1$ & 17.14 & $1.9 \pm 0.1$ & $\mathrm{nd}^{\mathrm{b}}$ \\
\hline 18:1n-9 & 17.71 & $\mathrm{nd}^{\mathrm{b}}$ & $3.4 \pm 0.1$ \\
\hline $18: 1 n-7$ & 17.78 & $17.3 \pm 0.1$ & $4.0 \pm 0.1$ \\
\hline Total MUFAs & & $24.3 \pm 0.1$ & $26.3 \pm 0.1$ \\
\hline \multicolumn{4}{|c|}{ Polyunsaturated fatty acids (PUFAs) } \\
\hline $14: 2$ & 13.53 & $1.6 \pm 0.1$ & $\mathrm{nd}^{\mathrm{b}}$ \\
\hline $16: 4 n-3$ & 15.61 & $6.4 \pm 0.1$ & $\mathrm{nd}^{\mathrm{b}}$ \\
\hline $18: 4 n-3$ & 17.70 & $8.6 \pm 0.1$ & $\mathrm{nd}^{\mathrm{b}}$ \\
\hline $18: 3 n-3$ & 17.77 & $0.5 \pm 0.1$ & $\mathrm{nd}^{\mathrm{b}}$ \\
\hline $18: 2 n-6$ & 17.80 & $3.7 \pm 0.1$ & $\mathrm{nd}^{\mathrm{b}}$ \\
\hline $18: 2 n-3$ & 17.87 & $8.4 \pm 0.1$ & $\mathrm{nd}^{\mathrm{b}}$ \\
\hline $20: 5 n-3$ & 19.21 & Trace & $5.0 \pm 0.1$ \\
\hline $20: 4 n-6$ & 19.33 & Trace & $9.8 \pm 0.1$ \\
\hline Total PUFAs & & $29.2 \pm 0.1$ & $14.8 \pm 0.1$ \\
\hline Total $n$-6 PUFAs & & $3.7 \pm 0.1$ & $9.8 \pm 0.1$ \\
\hline Total $n$-3 PUFAs & & $23.9 \pm 0.1$ & $5.0 \pm 0.1$ \\
\hline Ratio $n-6 / n-3$ & & $0.1 \pm 0.1$ & $1.9 \pm 0.1$ \\
\hline
\end{tabular}

${ }^{a}$ Methyl ester (\%) of total FA of total FA mixture; ${ }^{b}$ nd, not detected; ${ }^{c}$ ECLs, equivalent chain lengths; Minor FA $(\leq 0.1 \%)$, Docosenoic (22:1); Values are the mean of three replicates (mean $(\%$ dw) \pm s.d.); s.d., standard deviation.

The saturated fatty acids (SFAs) corresponded to $46.5 \%$ and $58.9 \%$ of TL from U. armoricana and $S$. chordalis, respectively. Their chain length ranged from $\mathrm{C}_{14}$ to $\mathrm{C}_{24}$ for $U$. armoricana and from $\mathrm{C}_{14}$ to $\mathrm{C}_{18}$ for $S$. chordalis. In the case of $U$. armoricana, the major SFAs were palmitic acid (42\%) and behenic acid (2.3\%). For S. chordalis, the major SFA were palmitic acid (45\%) and stearic acid (10\%). Monounsaturated FAs (MUFAs) contents were $24.3 \%$ for $U$. armoricana and $26.3 \%$ for $S$. chordalis. The predominant MUFAs were 16:1n-9 (2.7\%) and 18:1n-7 (17.3\%) for U. armoricana, and were 17:1n-7 (18.5\%), 18:1n-7 (4\%) and 18:1n-9 (3.4\%) for S. chordalis. 
PUFAs corresponded to $29.2 \%$ and $14.8 \%$ of the TL composition of U. armoricana and S. chordalis, respectively. The main PUFAs observed in U. armoricana TL were 16:4n-3 (6.4\%), 18:4n-3 (8.6\%), 18:2n-6 (3.7\%) and 18:2n-3 (8.4\%), with traces of arachidonic 20:4n-6 (AA), eicosapentaenoic 20:5n-3 (EPA), and docosahexaenoic 22:6n-3 (DHA) acids. In the case of S. chordalis, 20:4n-6 (9.8\%) and 20:5n-3 (5\%) acids were the major PUFAs.

These results are in agreement with the literature concerning seaweeds. Red seaweed species contain significant quantities of PUFA, up to 20 carbons, with four or five double bonds. Their two major PUFAs are $\mathrm{AA}$ and EPA. In addition, a high $\mathrm{C}_{20} / \mathrm{C}_{18}$ PUFA ratio is observed with high $\mathrm{C} 18: 1$ content [20]. Green seaweeds are characterized by $\mathrm{C}_{16}$ and $\mathrm{C}_{18}$ PUFA with a high $\mathrm{C}_{18} / \mathrm{C}_{20}$ PUFA ratio [14].

According to the literature, palmitic acid (16:0) is predominant in seaweeds [39]. As in the vegetative tissues of higher plants, the green algae contain primarily $\mathrm{C}_{16}$ and $\mathrm{C}_{18}$ fatty acids with a high degree of unsaturation [32]. The amount of $16: 4 n-3$ varies from $4.9 \%$ to $23.4 \%$, which is characteristic of green algae in addition with the presence of 16:3 [40]. Unlike red and brown algae, green algae contain large amounts of 16:3 and 16:4 PUFAs [40]. Johns et al. have proposed that 16:4 can be taxonomically characteristic of green macrophytic algae [41], as in plants of other divisions, it is only found in trace amount. Green algae are characterized by high contents of 18:2 and 18:3, like in land plants, U. armoricana being very rich in $\mathrm{C}_{18}$ PUFAs [13,42]. Linoleic acid $(18: 2 n-6)$ is the main PUFA of most chlorophytes $[13,14]$ and the $\alpha$-linolenic acid $(18: 3 n-3)$ is characteristic of the Ulvales $[13,14]$.

Furthermore, marine algae also contain the $n$-3 PUFAs. The $n-3$ long-chain PUFAs are abundant in most red algae, and this is similar for the $n-6$ long-chain PUFAs and 18:4n-3 [43].

In comparison with other species, the FA profiles obtained for $S$. chordalis were consistent with those reported in previous studies [13,19,20,22,25,43,44].

According to the literature, the PUFAs 20:4n-6 and 20:5n-3 are predominant in marine red algae, such as $S$. robusta and S. chordalis [13]. Furthermore, according to Aknin et al. [44] who reported the FAs composition of five Solieriaceae, almost 40 fatty acids were identified, the major fatty acids being 16:0, 16:1n-5, 4-OH-3,5-diiodo phenyl (dihydrohydnocarpic), 18:1n-9, 18:1n-7, 14:0, dihydrochaulmoogric, 18:1n-5, 20:4n-6 and 20:5n-3.

Although $U$. armoricana and $S$. chordalis displayed high amounts of SFA, the contents of PUFAs ranged from $14.8 \%$ to $29.2 \%$. It confirms that seaweeds contain significantly higher levels of PUFAs than land vegetables [6]. Interestingly, marine algae are rich in PUFA of the $\omega 3$ and $\omega 6$ series, which are considered essential FA. The World Health Organization currently recommends that the $n-6 / n-3$ ratio should not exceed 10 in a diet [45]. Therefore, U. armoricana and S. chordalis may be used for the reduction of the $n-6 / n-3$ ratio, as in TL, the $n$-3 PUFA of $U$. armoricana (23.9\%) is higher than the $n-6$ PUFA (3.7\%) and the $n$-3 PUFA of $S$. chordalis (5\%) is lower than the $n-6$ PUFA $(9.8 \%)$. The $n-6 / n-3$ ratio was established at 0.1 for $U$. armoricana and 1.9 for $S$. chordalis.

In addition, the benefits of PUFAs in human health are well documented, including cardiovascular effects [46]. Particularly, the $n$-3 PUFA may be beneficial for the prevention of several types of cancer, and exhibits various biological activities such as decrease of blood pressure and improvement of heart and liver function in body fat in animal trials [47]. Generally, the marine $n$-3 PUFAs exert anti-arteriosclerosis, anti-hypertensive, anti-inflammatory, immune-regulatory, antioxidant and anti-thrombotic effects, and antiarrhythmic responses [48]. In addition, they are precursors of the eicosanoids biosynthesis, which are bioregulators in many cellular processes [39]. The impact of $n-3$ PUFAs on brain function and mental 
health has also been recently examined, showing that they are able to improve the mitochondrial function [49]. Both AA and EPA are precursors of prostaglandins, thromboxane and other eicosanoids, which influence inflammation processes and immune reactions [47]. Linoleic acid, linolenic acid and arachidonic acid serve important functions in skin growth and protection. Finally, 20:4n-6, 20:5n-3, and 20:3n-6 lipids have valuable biological activities such as heart and mental health, arthritis, cancer and lung disease [13].

\subsubsection{Fatty Acid Composition of Phospholipids}

The PL FAs of $U$. armoricana and $S$. chordalis were identified by GC-MS analyses as FAMEs and $N$-acyl pyrrolidides (NAPs) as previously described for FAs of the TL. For many FAs, GC-MS data of the NAP derivatives allowed us to confirm their structures and to determine the location of double bonds, branching and hydroxyl groups [50].

More than 35 FAs were identified in PL of $U$. armoricana and 19 FAs in PL of $S$. chordalis as showed in Table 5.

Table 5. Fatty acid (\% of the phospholipids FAs mixture) of U. armoricana and $S$. chordalis.

\begin{tabular}{|c|c|c|c|}
\hline Fatty Acid (FAs) ${ }^{\text {a }}$ & $\mathbf{E C L}^{\mathbf{c}}$ & U. armoricana $(\%)$ & S. chordalis $(\%)$ \\
\hline \multicolumn{4}{|c|}{ Saturated fatty acids (SFAs) } \\
\hline 13:0 & 13.00 & $1.7 \pm 0.2$ & $\mathrm{nd}^{\mathrm{b}}$ \\
\hline 14:0 & 14.00 & $0.9 \pm 0.1$ & $2.3 \pm 0.1$ \\
\hline $15: 0$ & 15.00 & $0.2 \pm 0.2$ & $0.4 \pm 0.1$ \\
\hline $16: 0$ & 16.00 & $53.6 \pm 0.1$ & $29.0 \pm 0.1$ \\
\hline $17: 0$ & 17.00 & $0.4 \pm 0.1$ & $0.8 \pm 0.1$ \\
\hline 18:0 & 18.00 & $4.6 \pm 0.1$ & $5.0 \pm 0.1$ \\
\hline 19:0 & 19.00 & $0.2 \pm 0.0$ & $\mathrm{nd}^{\mathrm{b}}$ \\
\hline 20:0 & 20.00 & $0.3 \pm 0.1$ & $\mathrm{nd}^{\mathrm{b}}$ \\
\hline 21:0 & 21.00 & $0.2 \pm 0.0$ & $\mathrm{nd}^{\mathrm{b}}$ \\
\hline $22: 0$ & 22.00 & $1.9 \pm 0.2$ & $\mathrm{nd}^{\mathrm{b}}$ \\
\hline $24: 0$ & 24.00 & $0.3 \pm 0.1$ & $\mathrm{nd}^{\mathrm{b}}$ \\
\hline Total SFAs & & $64.3 \pm 0.1$ & $37.5 \pm 0.1$ \\
\hline \multicolumn{4}{|c|}{ Monounsaturated fatty acids (MUFAs) } \\
\hline $15: 1$ & 14.57 & $0.2 \pm 0.1$ & $\mathrm{nd}^{\mathrm{b}}$ \\
\hline $16: 1 n-11$ & 15.70 & $1.7 \pm 0.1$ & $\mathrm{nd}^{\mathrm{b}}$ \\
\hline $16: 1 n-8$ & 15.85 & $\mathrm{nd}^{\mathrm{b}}$ & $3.0 \pm 0.1$ \\
\hline $16: 1 n-7$ & 15.94 & $1.2 \pm 0.1$ & $\mathrm{nd}^{\mathrm{b}}$ \\
\hline $17: 1 n-14$ & 16.73 & $3.6 \pm 0.1$ & $\mathrm{nd}^{\mathrm{b}}$ \\
\hline $17: 1 n-7$ & 16.77 & $\mathrm{nd}^{\mathrm{b}}$ & $8.6 \pm 0.1$ \\
\hline $17: 1 n-4$ & 16.88 & $\mathrm{nd}^{\mathrm{b}}$ & $10.2 \pm 0.2$ \\
\hline 18:1n-9 & 17.71 & $\mathrm{nd}^{\mathrm{b}}$ & $2.2 \pm 0.2$ \\
\hline $18: 1 n-7$ & 17.78 & $5.8 \pm 0.1$ & $3.2 \pm 0.1$ \\
\hline $18: 1 n-3$ & 17.96 & $\mathrm{nd}^{\mathrm{b}}$ & $9.6 \pm 0.1$ \\
\hline 19:1 & 18.54 & $0.5 \pm 0.2$ & $\mathrm{nd}^{\mathrm{b}}$ \\
\hline $22: 1$ & 21.60 & $0.4 \pm 0.1$ & $\mathrm{nd}^{\mathrm{b}}$ \\
\hline Total MUFAs & & $13.4 \pm 0.1$ & $36.8 \pm 0.1$ \\
\hline
\end{tabular}


Table 5. Cont.

\begin{tabular}{|c|c|c|c|}
\hline \multicolumn{4}{|c|}{ Polyunsaturated fatty acids (PUFAs) } \\
\hline $16: 4 n-3$ & 15.60 & $2.2 \pm 0.1$ & $\mathrm{nd}^{\mathrm{b}}$ \\
\hline $18: 4 n-3$ & 17.70 & $3.3 \pm 0.1$ & $\mathrm{nd}^{\mathrm{b}}$ \\
\hline $18: 3$ & 17.75 & $\mathrm{nd}^{\mathrm{b}}$ & $1.2 \pm 0.2$ \\
\hline $18: 3 n-3$ & 17.77 & $7.6 \pm 0.2$ & $\mathrm{nd}^{\mathrm{b}}$ \\
\hline $18: 2$ & 17.79 & $\mathrm{nd}^{\mathrm{b}}$ & $2.1 \pm 0.1$ \\
\hline $18: 2 n-6$ & 17.80 & $1.7 \pm 0.2$ & $\mathrm{nd}^{\mathrm{b}}$ \\
\hline $20: 5 n-3$ & 19.21 & $0.4 \pm 0.1$ & $2.6 \pm 0.1$ \\
\hline $20: 4 n-6$ & 19.32 & $0.4 \pm 0.1$ & $12.2 \pm 0.1$ \\
\hline $20: 3 n-9$ & 19.44 & $0.4 \pm 0.1$ & $\mathrm{nd}^{\mathrm{b}}$ \\
\hline $20: 2$ & 19.56 & $0.4 \pm 0.1$ & $\mathrm{nd}^{\mathrm{b}}$ \\
\hline $21: 3$ & 20.64 & $0.4 \pm 0.1$ & $\mathrm{nd}^{\mathrm{b}}$ \\
\hline $22: 6 n-3$ & 21.54 & $0.3 \pm 0.1$ & $\mathrm{nd}^{\mathrm{b}}$ \\
\hline $22: 5$ & 21.63 & $0.8 \pm 0.1$ & $\mathrm{nd}^{\mathrm{b}}$ \\
\hline $22: 3$ & 21.83 & $0.6 \pm 0.1$ & $\mathrm{nd}^{\mathrm{b}}$ \\
\hline Total PUFAs & & $18.5 \pm 0.1$ & $18.1 \pm 0.1$ \\
\hline \multicolumn{4}{|c|}{ Hydroxy fatty acids (Hydroxy FAs) } \\
\hline \multicolumn{4}{|l|}{ 2-Hydroxy FAs } \\
\hline 2-OH-16:1 & 17.18 & $\mathrm{nd}^{\mathrm{b}}$ & $1.5 \pm 0.1$ \\
\hline $2-\mathrm{OH}-16: 0$ & 17.31 & $1.0 \pm 0.1$ & $1.4 \pm 0.1$ \\
\hline 2-OH-17:0 & 18.26 & $0.2 \pm 0.1$ & $4.5 \pm 0.1$ \\
\hline 2-OH-18:0 & 19.24 & $1.0 \pm 0.1$ & $\mathrm{nd}^{\mathrm{b}}$ \\
\hline 2-OH-22:0 & 23.26 & $0.1 \pm 0.1$ & $\mathrm{nd}^{\mathrm{b}}$ \\
\hline \multicolumn{4}{|l|}{ 3-Hydroxy FAs } \\
\hline 3-OH-17:1 & 18.53 & $0.2 \pm 0.1$ & $\mathrm{nd}^{\mathrm{b}}$ \\
\hline Total Hydroxy FAs & & $2.5 \pm 0.1$ & $7.4 \pm 0.1$ \\
\hline $\begin{array}{l}\text { Total Fatty aldehyde } \\
\text { dimethylacetals }\end{array}$ & & $1.3 \pm 0.1$ & nd $^{b}$ \\
\hline Total $n-6$ PUFAs & & $2.1 \pm 0.1$ & $12.2 \pm 0.1$ \\
\hline Total $n$-3 PUFAs & & $13.8 \pm 0.1$ & $12.2 \pm 0.1$ \\
\hline Ratio $n-6 / n-3$ & & $0.1 \pm 0.1$ & $\mathbf{1 . 0} \pm \mathbf{0 . 1}$ \\
\hline
\end{tabular}

${ }^{\mathrm{a}}$ Methyl ester (\%) of total FA of total FA of total PL; ${ }^{\mathrm{b}}$ nd, not detected; ${ }^{\mathrm{c}}$ ECLs, equivalent chain lengths; Values are the mean of three replicates (mean $(\% \mathrm{dw}) \pm$ s.d.); s.d., standard deviation.

The SFAs represented $64.3 \%$ and $37.5 \%$ of the PL from U. armoricana and S. chordalis, respectively. They ranged from $\mathrm{C}_{13}$ to $\mathrm{C}_{24}$ for $U$. armoricana and from $\mathrm{C}_{14}$ to $\mathrm{C}_{18}$ for $S$. chordalis. The major SFAs for U. armoricana were palmitic acid (53.6\%), and stearic acid (4.6\%). For S. chordalis, the main SFAs were myristic acid (2.3\%), palmitic acid (29\%) and stearic acid (5\%).

MUFAs content represented $13.4 \%$ and $36.8 \%$ of PL fraction for U. armoricana and S. chordalis, respectively. The main MUFAs of $U$. armoricana were 17:1n-14 (3.6\%) and 18:1n-7 (5.8\%). In the case of S. chordalis, the major MUFAs were 16:1n-8 (3\%), 17:1n-7 (8.6\%), 17:1n-4 (10.2\%), 18:1n-7 (3.2\%) and $18: 1 n-3(9.6 \%)$.

PUFAs content of the PL fraction corresponded to $18.5 \%$ and $18.1 \%$ for $U$. armoricana and S. chordalis, respectively. The main PUFAs in U. armoricana PL were 16:4n-3 (2\%), 18:4n-3 (3.3\%), 
18:3n-3 (7.6\%) and 18:2n-6 (1.7\%). In addition, AA, EPA, and DHA acids were also detected as minor constituents. In the case of $S$. chordalis, 20:4n-6 and 20:5n-3 acids were the major PUFAs (12.2\% and $3 \%$, respectively). Their contents are higher than in edible red seaweeds such as Chondrus crispus or Gracilaria verrucosa and commercial fish oils [22].

Regarding the $n-6 / n-3$ ratio, it was established at 0.1 for $U$. armoricana and 1 for $S$. chordalis. Five hydroxy FAs were identified in PL of $U$. armoricana representing 2.5\%, including four 2-hydroxy FA $\left(\mathrm{C}_{16}-\mathrm{C}_{22}\right)$ and one monounsaturated 3-hydroxy FA $\left(\mathrm{C}_{17}\right)$. Three hydroxy FA were identified in PL of $S$. chordalis corresponding to $7.4 \%$, including 2-hydroxy FA $\left(\mathrm{C}_{16}-\mathrm{C}_{17}\right)$, whose one monounsaturated 2-hydroxy acids $\left(\mathrm{C}_{16}\right)$ (Table 5). To our knowledge, these two monounsaturated 2-hydroxy and 3-hydroxy FA are reported in seaweeds for the first time.

All the spectra of the 2-hydroxy FAME exhibited molecular ions and other diagnostic fragment ions such as the ions at $\mathrm{m} / \mathrm{z} 90$ arising from the McLafferty rearrangement (instead of the usual $\mathrm{m} / \mathrm{z} 74$ for FAME) and $m / z 103$, the ion $[\mathrm{M}-\mathrm{MeOH}]^{+}$, and a relatively intense $[\mathrm{M}-\mathrm{COOMe}]^{+}$ion $[25,28,50-53]$. The mass spectra of their NAP derivatives showed the molecular ion peak and prominent peaks at $\mathrm{m} / \mathrm{z} 98$ and 100, and a base peak at $m / z 129$ (McLafferty, $113+16$ ). 3-Hydroxy FA was identified since the mass spectra of methyl esters and NAP derivatives showed base peaks at $\mathrm{m} / \mathrm{z} 103$ and 142, respectively $[28,52]$.

The 2- and 3-hydroxy FA are only minor constituents of PL FA but they are ubiquitous in nature. They have been reported in marine sponge lipids, which is a marine organism that has bacterial symbiosis [50,51], and in the red algae Schizymenia dubyi (Gigartinales) [52] and G. turuturu (Halymeniales) [53]. Matsumoto et al. reported that 3- and 2-hydroxy FA in microalgae may be used to classify algal species [54]. Bacteria are also recognized as an important source of the hydroxy FA in the natural environment [55], and the 2-hydroxy FA are known to occur in sulfate-reducing bacteria [56]. Several short-chains 3-hydroxy FA were reported as antifungal substances [57], demonstrating that 2- and 3-hydroxy FA are able to influence the membrane properties. For instance, at lower temperatures, some bacteria modify their membranous fatty acid composition by increasing the amount of 2- and 3-hydroxy FA for maintaining the functional homeoviscous state of their membrane [19]. Moreover, there are several examples of close associations between bacteria and algae [58,59].

In addition, it is the first time that monounsaturated 3-hydroxy $\mathrm{C}_{17}$ was identified in U. armoricana. Until now, the 3-hydroxy short-chain acids were known as typical bacterial FA. Thus, this hydroxy FA identified in $U$. armoricana could be of symbiotic origin.

Furthermore, unidentified aldehyde dimethylacetals (DMA), were detected at trace levels in the FA of PL of $U$. armoricana. Their mass spectra displaying the characteristic fragment ion $\mathrm{m} / z 75$ $\left(\left[\left(\mathrm{CH}_{3} \mathrm{O}\right)_{2}-\mathrm{CH}\right]^{+}\right)$as the base peak [51]. DMA revealed the presence of particular PL named plasmalogens known for various biological properties probably including protection against oxidation [60]. Such compounds have been reported from sponges and mollusks [51], and, very recently, in our previous study performed on G. turuturu [25].

In addition, variations in the FA composition can be attributed to environmental conditions, habitat, light, salinity, pollution, species and genetic status, location and seasonality, geography of development of the seaweed and to the method used for extracting oil [43]. Some recent investigations have demonstrated that FA profiles were specific to taxonomic groups [20,43,61,62]. Al-Hasan et al. have reported 
variations in macroalgae FA concentrations, but not in the composition pattern when the temperature varied [63]. According to Hotimchenko, light conditions influence the FA lipid contents and ratios [64].

In red seaweed, phosphatidylcholine and phosphatidylglycerol have been reported to be the major polar phospholipids, besides minor phosphatidylethanolamine, diphosphatidylglycerol and unidentified compounds [65].

\subsubsection{Fatty Acid Composition of Glycolipids}

Glycolipids of $S$. chordalis were the main lipid group and the second for $U$. armoricana. The glycolipid composition from the two algae was analyzed by thin layer chromatography (TLC), as shown in Table 6. Both U. armoricana and S. chordalis were composed of monogalactosyldiacylglycerols (MGDG) (44\% and 44.9\%, respectively) digalactosyldiacylglycerols (DGDG) (28.8\% and 23\%, respectively), and sulfoquinovosyl diacylglycerols (SQDG) (27.2\% and 32\%, respectively).

Table 6. Glycolipids composition (\% wt/wt) of U. armoricana and S. chordalis.

\begin{tabular}{lcc}
\hline & U. armoricana & S. chordalis \\
\hline MGDG $^{\text {a }}$ & 44.0 & 44.9 \\
DGDG $^{\text {b }}$ & 28.8 & 23.0 \\
$\mathrm{SQDG}^{\text {c }}$ & 27.2 & 32.0 \\
\hline
\end{tabular}

${ }^{a}$ MGDG, monogalactosyldiacylglycerols; ${ }^{\mathrm{b}}$ DGDG, digalactosyldiglycerols; ${ }^{\mathrm{c}}$ SQDG, sulfoquinovosyl diacylglycerols.

The GL FAs of $U$. armoricana and $S$. chordalis were identified by GC-MS analyses as FAME and NAP. The FAs composition of GL is given in Table 7. More than 33 FAs were identified in GL of $U$. armoricana and more than 25 FAs in GL of $S$. chordalis, as shown in Table 7.

Table 7. Fatty acid (\% of the glycolipids FAs mixture) of U. armoricana and S. chordalis.

\begin{tabular}{|c|c|c|c|}
\hline Fatty Acid (FAs) ${ }^{a}$ & $\mathrm{ECL}^{\mathrm{c}}$ & U. armoricana ${ }^{\mathrm{b}}(\%)$ & S. chordalis b $(\%)$ \\
\hline \multicolumn{4}{|c|}{ Saturated fatty acids (SFAs) } \\
\hline $12: 0$ & 12.00 & 0.04 & $\mathrm{nd}^{\mathrm{b}}$ \\
\hline $14: 0$ & 14.00 & 0.6 & 3.2 \\
\hline br-15:0 & 14.46 & 0.04 & $\mathrm{nd}^{\mathrm{b}}$ \\
\hline iso-15:0 & 14.53 & 0.08 & 0.1 \\
\hline$a i-15: 0$ & 14.63 & 0.5 & $\mathrm{nd}^{\mathrm{b}}$ \\
\hline $15: 0$ & 15.00 & 0.3 & 0.4 \\
\hline $16: 0$ & 16.00 & 64.2 & 40.0 \\
\hline$a i-17: 0$ & 16.72 & 0.5 & $\mathrm{nd}^{\mathrm{b}}$ \\
\hline $17: 0$ & 17.00 & 2.3 & 5.1 \\
\hline $18: 0$ & 18.00 & $\mathrm{nd}^{\mathrm{b}}$ & 3.1 \\
\hline 19:0 & 19.00 & 1.2 & 9.9 \\
\hline 20:0 & 20.00 & 0.2 & 0.1 \\
\hline 21:0 & 21.00 & 2.4 & $\mathrm{nd}^{\mathrm{b}}$ \\
\hline $22: 0$ & 22.00 & 2.3 & 0.1 \\
\hline 23 & 23.00 & 0.1 & $\mathrm{nd}^{\mathrm{b}}$ \\
\hline $24: 0$ & 24.00 & 0.5 & 0.7 \\
\hline Total SFAs & & 75.2 & 62.7 \\
\hline
\end{tabular}


Table 7. Cont.

\begin{tabular}{|c|c|c|c|}
\hline \multicolumn{4}{|c|}{ Monounsaturated fatty acids (MUFAs) } \\
\hline $13: 1$ & 12.72 & 1.5 & $\mathrm{nd}^{\mathrm{b}}$ \\
\hline $15: 1$ & 14.57 & 2.5 & $\mathrm{nd}^{\mathrm{b}}$ \\
\hline $16: 1 n-5$ & 15.86 & $\mathrm{nd}^{\mathrm{b}}$ & 4.1 \\
\hline $16: 1 n-9$ & 15.79 & 0.5 & $\mathrm{nd}^{\mathrm{b}}$ \\
\hline $16: 1 n-7$ & 15.94 & 2.1 & $\mathrm{nd}^{\mathrm{b}}$ \\
\hline $17: 1 n-5$ & 16.80 & $\mathrm{nd}^{\mathrm{b}}$ & 15.4 \\
\hline $17: 1 n-4$ & 16.88 & $\mathrm{nd}^{\mathrm{b}}$ & 0.5 \\
\hline $18: 1 n-9$ & 17.71 & $\mathrm{nd}^{\mathrm{b}}$ & 3.6 \\
\hline $18: 1 n-7$ & 17.78 & 3.5 & $\mathrm{nd}^{\mathrm{b}}$ \\
\hline $18: 1 n-5$ & 17.84 & $\mathrm{nd}^{\mathrm{b}}$ & 1.6 \\
\hline 19:1 & 18.86 & $\mathrm{nd}^{\mathrm{b}}$ & 1.4 \\
\hline Total MUFAs & & 10.1 & 26.6 \\
\hline \multicolumn{4}{|c|}{ Polyunsaturated fatty acids (PUFAs) } \\
\hline $16: 4 n-3$ & 15.61 & 2.1 & $\mathrm{nd}^{\mathrm{b}}$ \\
\hline $18: 4 n-3$ & 17.70 & 0.2 & $\mathrm{nd}^{\mathrm{b}}$ \\
\hline $18: 3 n-3$ & 17.77 & 3.5 & $\mathrm{nd}^{\mathrm{b}}$ \\
\hline $18: 2$ & 17.79 & $\mathrm{nd}^{\mathrm{b}}$ & 0.2 \\
\hline $18: 2 n-6$ & 17.80 & 0.6 & $\mathrm{nd}^{\mathrm{b}}$ \\
\hline $18: 2 n-3$ & 17.87 & 1.8 & $\mathrm{nd}^{\mathrm{b}}$ \\
\hline $20: 5 n-3$ & 19.21 & $\mathrm{nd}^{\mathrm{b}}$ & 1.2 \\
\hline $20: 4 n-6$ & 19.32 & $\mathrm{nd}^{\mathrm{b}}$ & 2.1 \\
\hline $22: 6 n-3$ & 21.54 & 0.9 & $\mathrm{nd}^{\mathrm{b}}$ \\
\hline $22: 3$ & 21.83 & $\mathrm{nd}^{\mathrm{b}}$ & 0.9 \\
\hline Total PUFAs & & 9.0 & 4.5 \\
\hline \multicolumn{4}{|c|}{ Hydroxy fatty acids (Hydroxy FAs) } \\
\hline \multicolumn{4}{|l|}{ 2-Hydroxy FAs } \\
\hline 2-OH-14:0 & 15.57 & 0.04 & $\mathrm{nd}^{\mathrm{b}}$ \\
\hline 2-OH-16:0 & 17.30 & 0.8 & 0.4 \\
\hline 2-OH-18:0 & 19.23 & 0.2 & 2.7 \\
\hline 2-OH-20:0 & 21.45 & 0.4 & $\mathrm{nd}^{\mathrm{b}}$ \\
\hline 2-OH-22:0 & 23.26 & 0.2 & 0.6 \\
\hline \multicolumn{4}{|l|}{ 3-Hydroxy FAs } \\
\hline 3-OH-16:0 & 17.64 & $\mathrm{nd}^{\mathrm{b}}$ & 0.5 \\
\hline $3-\mathrm{OH}-17: 0$ & 18.55 & 1.5 & 0.9 \\
\hline 3-OH-18:0 & 19.46 & 0.3 & $\mathrm{nd}^{\mathrm{b}}$ \\
\hline Total Hydroxy FAs & & 3.5 & 5.1 \\
\hline Other compounds ${ }^{d}$ & & 2.2 & 0.7 \\
\hline Total n-6 PUFAs & & 0.6 & 2.1 \\
\hline Total $n$-3 PUFAs & & 8.5 & 1.2 \\
\hline Ratio $n-6 / n-3$ & & $\mathbf{0 . 0 7}$ & 1.7 \\
\hline
\end{tabular}

${ }^{\mathrm{a}}$ Methyl ester (\%) of the glycolipids FAs mixture; ${ }^{\mathrm{b}}$ nd, not detected; ${ }^{\mathrm{c}}$ ECLs, equivalent chain lengths; $i$, iso; ai, anteiso; br, branched. Values are the mean of three replicates (mean $\% \mathrm{dw}$ ); ${ }^{\mathrm{d}}$ Mass spectra of the compounds showed characteristic intense fragment ion at $m / z 75$. 
The SFAs represent $75.2 \%$ and $62.7 \%$ of the GL from U. armoricana and S. chordalis, respectively. They ranged from $\mathrm{C}_{12}$ to $\mathrm{C}_{24}$ for $U$. armoricana and from $\mathrm{C}_{14}$ to $\mathrm{C}_{24}$ for $S$. chordalis. The major SFA for U. armoricana was palmitic acid (64.2\%). For S. chordalis, the main SFAs were myristic acid (3.2\%), palmitic acid (40\%), margaric acid (5.1\%) and nonadecylic acid (9.9\%) (Table 7).

Four branched-chain FA with short-chains were detected (br-15:0, iso-15:0, ai-15:0, and ai-17:0). Branched-chain FAs (iso and anteiso) are typical for the occurrence of bacteria and other monomethyl-branched short-chain FAs probably have the same origin [66]. Branched-chain FAs are characteristic of gram-positive bacteria [66].

MUFAs contents represented $10.1 \%$ and $26.6 \%$ of GL fraction for $U$. armoricana and $S$. chordalis, respectively. The main MUFA of $U$. armoricana were 15:1 (2.5\%), 16:1n-7 (2.1\%) and 18:1n-7 (3.5\%). In the case of $S$. chordalis, the major MUFA were 16:1n-5 (4.1\%), 17:1n-5 (15.4\%) and 18:1n-9 (3.6\%).

PUFAs content of the GL fraction corresponded to $9 \%$ and $4.5 \%$ for U. armoricana and S. chordalis, respectively. The main PUFAs in $U$. armoricana GL were 16:4n-3 (2.1\%) and 18:3n-3 (3.5\%). In addition, DHA acid was also detected as minor constituent. In the case of $S$. chordalis, 20:4n-6 and $20: 5 n-3$ acids were the major PUFAs (2.1\% and $1.2 \%$, respectively).

Regarding the $n-6 / n-3$ ratio, it was established at 0.07 for $U$. armoricana and 1.7 for $S$. chordalis.

Seven hydroxy FAs were identified in GL of $U$. armoricana at 2.2\%, including five 2-hydroxy FA $\left(\mathrm{C}_{14}-\mathrm{C}_{22}\right)$ and two 3-hydroxy FAs $\left(\mathrm{C}_{17}-\mathrm{C}_{18}\right)$. Five hydroxy FA were identified in GL of $S$. chordalis at $0.7 \%$, including three 2-hydroxy FA $\left(\mathrm{C}_{16}-\mathrm{C}_{12}\right)$ and two 3-hydroxy acids $\left(\mathrm{C}_{16}-\mathrm{C}_{18}\right)$. Moreover, it is the first time that 3-hydroxy short-chain acids were identified in $U$. armoricana and $S$. chordalis. Until now, the 3-hydroxy short-chain acids were known as typical bacterial FA. Thus, these hydroxy FA identified in U. armoricana and S. chordalis could be of symbiotic origin [50,51].

\subsection{Antiproliferative Activity against Human Non-Small Cell Lung Cancer}

This present study particularly focuses on the valorization of the major glycolipids, such as MGDG and DGDG. These lipids are reported to exhibit diverse biological functions, particularly antitumor activity, especially those from marine organisms.

The effect of MGDG and DGDG from $U$. armoricana and $S$. chordalis was evaluated for their capacity to inhibit in vitro the growth of human tumor cell Lines: NSCLC-N6 cell lines derived from a human non-small-cell bronchopulmonary carcinoma (moderately differentiated, rarely keratinized, classified as $\mathrm{T} 2 \mathrm{~N} 0 \mathrm{M} 0$ ).

The results showed that only MGDG classes from $S$. chordalis were active against NSCLC-N6 cell lines with $\mathrm{IC}_{50}=23.5 \pm 1.3 \mu \mathrm{g} / \mathrm{mL}$, and $24.0 \pm 0.3 \mu \mathrm{g} / \mathrm{mL}$ for DGDG in U. armoricana.

Silva et al. showed that Ulva rigida and the red macroalga Gelidium microdon Kützing (Gelidiales), collected from the Azorean archipelago, exhibited in vitro growth inhibitory effect on human tumor cell lines: NCI-H460 (non-small cell lung cancer) [67]. The crude methanol extracts (after removal of chlorophylls) of both macroalgae were found moderately active against cell lines ( $\mathrm{IC}_{50}=42 \mu \mathrm{g} / \mathrm{mL}$ for $U$. rigida and $\mathrm{IC}_{50}=65 \mu \mathrm{g} / \mathrm{mL}$ for $G$. microdon). 


\subsection{Proposed Algal Glycolipid Structures of Bioactive Constituents}

To further identify the active constituents of $U$. armoricana and S. chordalis GL fraction, they were profiled by liquid chromatography coupled to high resolution mass spectrometry (HR-MS) [68]. The combination of the HR-MS data with the FA composition obtained by GC-MS of the active fraction was used to identify compounds responsible of the observed antitumor activity.

From the $U$. armoricana, the activity of the DGDG fraction was related to an ion $\mathrm{m} / z=887.573 \mathrm{Da}$ corresponding to the molecular formula of $\mathrm{C}_{47} \mathrm{H}_{82} \mathrm{O}_{15}$. This corresponded to a DGDG containing two Fas, 14:0 and 18:3n-3 (the major PUFA in DGDG). In the case of $S$. chordalis MGDG fraction, the antitumor activity was related to an ion $\mathrm{m} / z=708.399 \mathrm{Da}$ corresponding to the molecular formula of $\mathrm{C}_{39} \mathrm{H}_{62} \mathrm{O}_{10}$, the two FAs branched on the MGDG being 14:0 and 16:1n-5. In both cases the S1 and S2 position on the glycerol as well as the sugar moiety was undetermined.

\section{Materials and Methods}

\subsection{Samples}

Ulva armoricana (Ulvales, Chlorophyceae) was collected on the beach in Plestin-les-Grèves (48 $39^{\prime} 28^{\prime \prime}$ N, 337'47" W), English Channel (Brittany, France), on 18 June 2012. Solieria chordalis (Rhodophyta, Gigartinales, Solieriaceae) was collected in October 2013 from the littoral zone of the Saint Gildas de Rhuys ( $47^{\circ} 30^{\prime} 0^{\prime \prime}$ N, $2^{\circ} 49^{\prime} 60^{\prime \prime}$ W, Atlantic coast, France). The algae were stored, and then thoroughly cleaned to remove epiphytes, sediment, organic debris, and macrofauna. Samples were successively rinsed with distilled water. The seaweeds were ground to pieces of about $3 \mathrm{~mm}$ with a hammer mill. The crushed seaweeds were frozen immediately at $-25^{\circ} \mathrm{C}$ and were thawed at the time of lipid analysis. The moisture content $(\%, \mathrm{MC})$ of seaweeds was determined by drying $2.00 \mathrm{~g}$ of samples in a thermo regulated incubator at $105{ }^{\circ} \mathrm{C}$ until constant weight and water content was determined gravimetrically. $\mathrm{MC}(\%)=\left(m_{\mathrm{i}}-m_{\mathrm{od}} / m_{\mathrm{i}}\right) \times 100$; with $m_{\mathrm{i}}=$ initial mass of wet seaweed specimen; $m_{\mathrm{od}}=$ oven dry mass of seaweed specimen.

\subsection{Lipid Extraction, Lipid Classes, Fatty Acid and Sterol}

Total lipids were extracted from fresh algae crushed $(1 \mathrm{~kg})$, with a mixture of chloroform $/ \mathrm{methanol}$ $(1: 1, v / v)$ over 2 days at room temperature under agitation for $5 \mathrm{~h}$. The extract was filtered using a Büchner funnel and washed with distilled water. The lipid content was determined by the gravimetric method and as a percentage of the algae dry weight.

The proportion of lipid relative to the dry mass corresponds to the weight ratio of the total lipid extract and biomass. The percentage (\%) of lipid was calculated according to the following equation: $\%$ Fat $=$ total lipid/(total lipid + dry mass without lipid $) \times 100$. Mass of dry S. chordalis $=71.8 \mathrm{~g}$; Mass of lipid content of $S$. chordalis $=2.2 \mathrm{~g}$; Mass of dry U. armoricana $=88.6 \mathrm{~g}$; Mass of lipid content of $U$. armoricana $=2.4 \mathrm{~g}$.

One part of lipids ( $1 \mathrm{~g}$ ) was fractionated into NL (dichloromethane), GL (acetone) and PL (methanol) by normal phase on flash column chromatography (SI-Std, $25 \mathrm{G}, 50 \mu \mathrm{m}, 22 \mathrm{bar}, 20 \mathrm{~mL} / \mathrm{mn}, \mathrm{IR}-50 \mathrm{SI} / 25 \mathrm{G}$, Puri Flash ${ }^{\circledR}$ Interchim, Montluçon, France). Fractions were evaporated to dryness and the percentage 
was determined as percentage of $1 \mathrm{~g}$ of lipids. Another part of lipids (50 mg) was saponified with $2 \mathrm{M}$ ethanolic potassium hydroxide. A part of the unsaponifiable matter was acetylated using acetic anhydride and pyridine giving a mixture containing sterol acetates. The aqueous phase containing potassium salts of FA was acidified by $2 \mathrm{M} \mathrm{HCl}(\mathrm{pH}=4-5)$ and FA were extracted by dichloromethane. FAMEs were prepared by transmethylation $\left(1 \mathrm{~h}\right.$ at $80{ }^{\circ} \mathrm{C}$ with $6 \%$ methanolic hydrogen chloride). A part of these FAMEs was heated at $85{ }^{\circ} \mathrm{C}$ in a mixture of pyrrolidine and acetic acid for $1 \mathrm{~h}$ in order to obtain the $\mathrm{N}$-acyl pyrrolidides (NAP). The FAMEs of GL were obtained by acidic methanolysis by heating $10 \mathrm{mg}$ of GL with methanol/water/hydrochloric acid $(29: 4: 3, \mathrm{v} / \mathrm{v} / \mathrm{v}, 5 \mathrm{~mL})$ at $80{ }^{\circ} \mathrm{C}$ for $18 \mathrm{~h}$. The reaction mixture was extracted with water/hexane $(3: 9, \mathrm{v} / \mathrm{v}, 12 \mathrm{~mL})$, the organic layer containing the FAME mixture was dried on anhydrous sodium sulfate, filtered and weighed after solvent evaporation. A part $(1 / 3)$ of the FAME was preserved; the other was transformed into NAP, as described above.

Total FAs derivatives, PL FAs derivatives and GL FAs derivatives (FAME and NAP), sterols (as free forms and acetates), NL, were analyzed by gas chromatography coupled with mass spectrometry (GC-MS).

\subsection{Thin Layer Chromatography}

Thin layer chromatography (TLC) was carried out for the whole of sterols and glycolipids, in order to visualize the families of products. Thin layer chromatography was carried out on a plate of size $20 \mathrm{~cm} \times 20 \mathrm{~cm}$, consisted of an analytical polyester support and of a silica gel (60F254, $60 \AA, 15 \mu \mathrm{m})$ of $0.25 \mathrm{~mm}$ thickness.

The sterols and unsaponifiable fractions composition were studied by TLC in addition to the analysis by GC-MS, using hexane, diethyl ether and acetic acid as eluent (85:15:0.1, v/v/v, double elution), with a standard cholesterol and cholesterol acetate, phytol, $\beta$ carotene. Plates were visualized by spraying with sulfuric vanillin followed by heating in an oven.

As to the glycolipid class composition, the mobile phase was dichloromethane/methanol $(85: 15, \mathrm{v} / \mathrm{v}$, double elution). In this case, standards used were monogalactosyldiglycerols (MGDG) (from spinach leaves and identified by nuclear magnetic resonance), digalactosyldiglycerols (DGDG), sulfoquinovosyl monoacylglycerols (SQMG) and sulfoquinovosyl diacylglycerols (SQDG) purchased from Sigma-Aldrich Co. (Saint-Quentin Fallavier, France). Plates were revealed by orcinol/sulfuric acid followed by heating in an oven.

\subsection{Gas Chromatography-Mass Spectrometry Analyses of Fatty Acid and Sterol Derivatives}

FAMEs, NAPs, sterols (as free forms and acetates), and neutral lipids were analyzed by GC-MS. The samples were analyzed using a Hewlett Packard 6890 series GC system coupled with a MS HP 6890 series, equipped with silica capillary column SLB ${ }^{\mathrm{TM}}-5 \mathrm{~ms}(60 \mathrm{~m} \times 0.25 \mathrm{~mm} \times 0.25 \mu \mathrm{m})$, the carrier gas was helium $\left(1 \mathrm{~mL} \cdot \mathrm{min}^{-1}\right)$. The analyses were carried out in electron impact $(70 \mathrm{eV})$. Detector was set at $280^{\circ} \mathrm{C}$, and the injector at $250{ }^{\circ} \mathrm{C}$. The samples were injected in splitless mode. Helium was used as the carrier gas under a constant flow rate $(1 \mathrm{~mL} / \mathrm{min})$. Three different temperature gradients were used for FAME analysis, as follows: temperature was held at $170{ }^{\circ} \mathrm{C}$ for $4 \mathrm{~min}$ and programmed to $300{ }^{\circ} \mathrm{C}$ at $3{ }^{\circ} \mathrm{C} \cdot \mathrm{min}^{-1}$; for NAP analysis, $200{ }^{\circ} \mathrm{C}$ for $4 \mathrm{~min}$ then $3{ }^{\circ} \mathrm{C} \cdot \mathrm{min}^{-1}$ up to $310{ }^{\circ} \mathrm{C}$ and held for $20 \mathrm{~min}$; and for sterols analysis, $200{ }^{\circ} \mathrm{C}$ then $3{ }^{\circ} \mathrm{C} \cdot \mathrm{min}^{-1}$ to $310^{\circ} \mathrm{C}$ and held for $25 \mathrm{~min}$. The solvent delay was $7 \mathrm{~min}$ for FAME and NAP analyses and 8 min for sterols. 
The identification of FAs, sterols and unsaponifiable fractions is carried by identification their mass spectra. Thus, the FAs were identified as FAMEs by comparing their ECL values with those previously described or using commercial mixtures. The ECLs of the FAMEs were determined by expressing their elution positions relative to those of known straight-chain saturated FAME. The FAMEs were converted to $N$-acyl pyrrolidides in order to locate double bonds and branching.

\subsection{Cellular Studies (NSCLC-N6)}

The antiproliferative activity of glycolipids of $U$. armoricana and $S$. chordalis were evaluated on the NSCLC-N6 cell line [69] derived from a human non-small-cell bronchopulmonary carcinoma, moderately differentiated, rarely keratinized, classified as T2N0M0. The cell lines were cultured in RPMI 1640 medium with $5 \%$ fetal calf serum, to which were added $100 \mathrm{IU}$ penicillin $\cdot \mathrm{mL}^{-1}, 100 \mathrm{mg}$ streptomycin $\cdot \mathrm{mL}^{-1}$ and $2 \mathrm{mM}$ glutamine, at $37^{\circ} \mathrm{C}$ in an air/carbon dioxide atmosphere $(95: 5, \mathrm{v} / \mathrm{v})$.

Cytotoxicity was determined by continuous drug exposure. Experiments were performed in 96 wells microtiter plates $\left(105\right.$ cells $\cdot \mathrm{mL}^{-1}$ for NSCLC-N6). Cell growth was estimated by a colorimetric assay based on the conservation of tetrazolium dye (MTT) to a blue formazan product by live mitochondria [70]. Eight repeats were performed for each concentration. Control growth was estimated from 8 determinations. Optical density at $570 \mathrm{~nm}$ corresponding to solubilized formazan was read for each well on a Titertek Multiskan MKII. Experiments were performed at least in triplicate, 4 wells per glycolipid concentration being used. IC50 values were calculated from the dose-response curves.

\subsection{Liquid Chromatography-Mass Spectrometry Analysis of Glycolipids}

Active GL fractions were analyzed by high performance liquid chromatography coupled with an electrospray ionization ion trap time-of-flight multistage mass spectrometer (LCMS-IT-TOF) analyses to determine molecular formula. A Shimadzu LCMS-IT-TOF instrument composed of two LC-20ADxr pumps, a SIL-20ACxr autosampler, a CTO-20AC column oven, a SPD-M20A DAD detector, a CBM-20A system controller, an ESI ion source, and an IT-TOF mass spectrometer (Shimadzu, Kyoto, Japan) was used. Chromatographic conditions were adapted from Knittelfelder et al. [68]. LC-MS profiles were recorded with a $150 \times 2.1 \mathrm{~mm}, 2.6 \mu \mathrm{m}$ Kinetex C18 column (Phenomenex) in gradient mode at a flow rate of $0.4 \mathrm{~mL} \cdot \mathrm{min}^{-1}$ at the temperature of $60{ }^{\circ} \mathrm{C}$. A solvent system composed of (A) water/MeOH 1:1 and (B) iso-propanol ; both eluant (A and B) being modified with $0.1 \% \mathrm{v} / \mathrm{v}$ formic acid and $10 \mathrm{mM}$ of ammonium formate. The gradient consisted of $5 \mathrm{~min}$ at $25 \% \mathrm{~B}$, followed by an increase to $45 \% \mathrm{~B}$ from $5 \mathrm{~min}$ to $13 \mathrm{~min}$, followed by an increase to $75.27 \% \mathrm{~B}$ from $13 \mathrm{~min}$ to $45 \mathrm{~min}$. The column was then washed with $100 \%$ iso-propanol for $7 \mathrm{~min}$ and re-equilibrated to $25 \% \mathrm{~B}$ for $7 \mathrm{~min}$. injection consisted of $2 \mu \mathrm{L}$ of solution at $1 \mathrm{mg} / \mathrm{mL}$ fraction in iso-propanol. The conditions of ESI-IT-TOF-MS analyses are listed below: (1) detection mode: positive ion and negative ion; (2) mass range: MS, $m / z$ 100-1200 Da; (3) heat block: $250{ }^{\circ} \mathrm{C}$ and curved desolvation line temperature: $230{ }^{\circ} \mathrm{C}$; nebulizing nitrogen gas flow: $1.5 \mathrm{~L} / \mathrm{min}$; interface voltage: $(+) 4.0 \mathrm{kV},(-) 3.5 \mathrm{kV}$; detector voltage of the TOF analyzer: $1.61 \mathrm{kV}$; for MS the ion accumulation time: (+) $20 \mathrm{~ms}$, (-) $5 \mathrm{~ms}$; (4) All data were recorded and analyzed by Shimadzu software: LCMS solution Version 3.60, Formula Predictor Version 1.2, and Accurate Mass Calculator (Shimadzu, Kyoto, Japan); and (5) a trifluoroacetic acid sodium solution $(2.5 \mathrm{mM})$ was used to calibrate the mass range from 100 to $1200 \mathrm{Da}$. 


\subsection{Statistical Analysis}

All measurements were made in triplicate for each alga $(n=3)$, except for GL analyses, which were carried out on only one sample. All data are reported as mean \pm standard deviation (SD). The statistical analysis was carried out on SPSS v20 (IBM, Chicago, IL, USA) using one-way analysis of variance (ANOVA).

\section{Conclusions}

The macroalgae $U$. armoricana and $S$. chordalis revealed low lipid contents. However, they exhibited high amounts of nutritionally essential $n-6$ and $n$-3 PUFAs, including EPA, AA, DHA, 16:4n-3, 18:4n-3, $18: 3 n-3,18: 2 n-3$, and 18:2n-6, but at lower levels than other edible red seaweeds such as Chondrus crispus or Gracilaria verrucosa. Therefore, U. armoricana and S. chordalis may be potential sources of $n-3$ and $n-6$ lipids. The health benefiting $n-6 / n-3$ ratio in macroalgae allows their use in the formulation of functional foods and nutraceuticals. In this study, U. armoricana and S. chordalis can be considered as a source of dietary PUFAs, since they showed $n-6 / n-3$ ratios ranging from 0.1 for $U$. armoricana to 1 for $S$. chordalis. Moreover, some FAs were identified for the first time in seaweeds as minor components such as 3-hydroxyoctadecanoic and the 2-hydroxy acid and two monounsaturated hydroxy acids. Hence, FAs compositions may provide a chemotaxonomic basis for macro-algae. These seaweeds contained interesting compounds such as phytol (precursor for the industrial synthesis of vitamins $\mathrm{E}$ and K), $\alpha$-tocopherol (vitamin E) and squalene. Phytosterols were identified, namely brassicasterol, chondrillasterol, fucosterol and isofucosterol. The sterol composition showed also the presence of cholest-4-en-3-one. It would be of interest to isolate and identify the most important ones in terms of biological activities. Interestingly, glycolipids (MGDG, DGDG and SQDG) from U. armoricana and $S$. chordalis showed promising anti-proliferative activities on cancer cell lines.

\section{Acknowledgments}

The authors thank Vony Rabesaotra from University of Nantes, Laboratory Mer-Molécules-Santé (MMS), EA 2160 - for her technical assistance; Christophe Tomasoni from University of Nantes, IICIMED/ERATU, Cancer du Poumon et Cibles Moléculaires for his technical assistance; and the PhD students Anne Sophie Burlot and Kevin Hardouin from University of Bretagne-Sud for collecting algae.

This work is part of research conducted as Teaching and Research Temporary Attaché (ATERs) at the Universite de Bretagne-Sud, LBCM Laboratory.

\section{Author Contributions}

Melha Kendel, Gaëtane Wielgosz-Collin, Samuel Bertrand, Christos Roussakis, Nathalie Bourgougnon and Gilles Bedoux conceived and designed the experiments; Melha Kendel, Gaëtane Wielgosz-Collin and Samuel Bertrand performed the experiments and analyzed the data; Melha Kendel, Gaëtane Wielgosz-Collin, Samuel Bertrand, Nathalie Bourgougnon and Gilles Bedoux wrote the paper. Melha Kendel, Gaëtane Wielgosz-Collin, Samuel Bertrand, Christos Roussakis, Nathalie Bourgougnon and Gilles Bedoux have been involved in the preparation and have approved the submitted manuscript. 


\title{
Conflicts of Interest
}

The authors declare no conflict of interest.

\begin{abstract}
Abbreviations
AA: arachidonic acid; ai: anteiso; br: branched; DHA: n-3 docosahexaenoic acid; DGDG: digalactosyldiglycerols; DMA: dimethylacetal; dw: dry weight; ECL: equivalent chain lengths; EPA: $n$-3 eicosapentaenoic acid; $\mathrm{FA}_{(\mathrm{s})}$ : fatty $\operatorname{acid}(\mathrm{s}) ; \mathrm{FAME}_{(\mathrm{s})}$ : fatty acid methyl ester(s); fw: fresh weight; GC-MS: gas chromatography-mass spectrometry; GL: glycolipids; HR-MS: high resolution mass spectrometry; IC50: 50\% inhibitory concentration; I: iso; LC-MS: liquid chromatography-mass spectrometry; LCMS-IT-TOF: liquid chromatography coupled with a electrospray ionization ion trap time-of-flight multistage mass spectrometer; la: lyophilized algae; MGDG: monogalactosyldiglycerols; MUFA(s): monounsaturated fatty acids; NAP: $N$-acyl pyrrolidide(s); NL: neutral lipids; PUFA(s): polyunsaturated fatty acid(s); PL: phospholipids; $\mathrm{SFA}_{(\mathrm{s})}$ : saturated fatty acids; SQDG: sulfoquinovosyl diacylglycerols; SQMG: sulfoquinovosyl monoacylglycerols; s.d.: standard deviation; TL: total lipids.
\end{abstract}

\section{References}

1. Stengel, D.B.; Connan, S.; Popper, Z.A. Algal chemodiversity and bioactivity: Sources of natural variability and implications for commercial application. Biotechnol. Adv. 2011, 29, 483-501.

2. Dawczynski, C.; Schubert, R.; Jahreis, G. Amino acids, fatty acids, and dietary fiber in edible seaweed products. Food Chem. 2007, 103, 891-899.

3. Newton, I.S. Long chain fatty acids in health and nutrition. J. Food Lipids 1996, 3, 233-249.

4. Rajasulochana, P.; Krishnamoorthy, P.; Dhamotharan, R. Amino acids, fatty acids and minerals in Kappaphycus sps. J. Agric. Biol. Sci. 2010, 5, 1-12.

5. Miyashita, K.; Mikami, N.; Hosokawa, M. Chemical and nutritional characteristics of brown seaweed lipids: A review. J. Funct. Foods 2013, 5, 1507-1517.

6. Darcy-Vrillon, B. Nutritional aspects of the developing use of marine macroalgae for the human food industry. Int. J. Food Sci. Nutr. 1993, 44, 23-35.

7. Hardouin, K.; Burlot, A.-S.; Umami, A.; Tanniou, A.; Stiger-Pouvreau, V.; Widowati, I.; Bedoux, G.; Bourgougnon, N. Biochemical and antiviral activities of enzymatic hydrolysates from different invasive French seaweeds. J. Appl. Phycol. 2014, 26, 1029-1042.

8. Dembitsky V.M.; Rozentsvet O.A. Diacylglyceryltrimethylhomoserines and phospholipids of some green marine macrophytes. Phytochemistry 1989, 28, 3341-3343.

9. Khairy Hanan, M.; El-Shafay Shimaa, M. Seasonal variations in the biochemical composition of some common seaweed species from the coast of Abu Qir Bay, Alexandria, Egypt. Oceanologia 2013, 55, 435-452.

10. Ambreen, Hira, K.; Tariq, A.; Ruqqia, Sultana, V.; Ara, J. Evaluation of biochemical component and antimicrobial activity of some seaweeds occurring at Karachi coast, Pakistan. J. Bot. 2012, 44, 1799-1803.

11. Yaich, H.; Garna, H.; Besbes, S.; Paquot, M.; Blecker, C.; Attia, H. Chemical composition and functional properties of Ulva lactuca seaweed collected in Tunisia. Food Chem. 2011, 128, 895-901. 
12. Banerjee, K.; Ghosh, R.; Homechaudhuri, S.; Mitra, A. Biochemical Composition of Marine Macroalgae from Gangetic Delta at the Apex of Bay of Bengal. Afr. J. Basic. Appl. Sci. 2009, 1, 96-104.

13. Li, X.; Fan, X.; Han, L.; Lou, Q. Fatty acids of some algae from the Bohai Sea. Phytochemistry 2002, 59, 157-161.

14. Khotimchenko, S.V.; Vaskovsky, V.E.; Titlyanova, T.V. Fatty acids of marine algae from the Pacific coast of north California. Bot. Mar. 2002, 45, 17-22.

15. Maehre, H.K.; Malde, M.K.; Eilertsen, K.-E.; Elvevoll, E.O. Characterization of protein, lipid and mineral contents in common Norwegian seaweeds and evaluation of their potential as food and feed. J. Sci. Food Agric. 2014, 94, 3281-3290.

16. Rohani-Ghadikolaei, K.; Abdulalian, E.; Ng, W.K. Evaluation of the proximate, fatty acid and mineral composition of representative green, brown and red seaweeds from the Persian Gulf of Iran as potential food and feed resources. J. Food Sci. Technol. 2012, 49, 774-780.

17. Santos, S.A.O.; Vilela, C.; Freire, C.S.R.; Abreu, M.H.; Rocha, S.M.; Silvestre, A.J.D. Chlorophyta and Rhodophyta macroalgae: A source of health promoting phytochemicals. Food Chem. 2015, $183,122-128$.

18. Ivanova, V.; Stancheva, M.; Petrova, D. Fatty acid composition of black sea Ulva rigida and Cystoseira crinita. Bulg. J. Agric. Sci. 2013, 19 (Suppl. 1), 42-47.

19. Colombo, M.L.; Rise, P.; Giavarini, F.; de Angelis, L.; Galli, C.; Bolis, C.L. Marine Macroalgae assources of polyunsaturated fatty acids. Plant Foods Hum. Nutr. 2006, 61, 67-72.

20. Kumari, P.; Bijo, A.J.; Mantri, V.A.; Reddy, C.R.K.; Jha, B. Fatty acid profiling of tropical marine macroalgae: An analysis from chemotaxonomic and nutritional perspectives. Phytochemistry 2013, $86,44-56$.

21. El Maghraby, D.M.; Fakhry, E.M. Lipid content and fatty acid composition of Mediterranean macro-algae as dynamic factors for biodiesel production. Oceanologia 2015, 57, 86-92.

22. Khotimchenko, S.V. Lipids from the marine alga Gracilaria verrucosa. Chem. Nat. Comp. 2005, 41, 285-288.

23. Li, Y.; Moore, R.B.; Qin, J.G.; Scott, A.; Ball, A.S. Extractable liquid, its energy and hydrocarbon content in the green alga Botryococcus braunii. Biomass Bioenergy 2013, 52, 103-112.

24. Sanchez-Machado, D.I.; Lopez-Cervantes, J.; Lopez-Hernandez, J.; Paseiro-Losada, P. Fatty acids, total lipid, protein and ash contents of processed edible seaweeds. Food Chem. 2004, 85, 439-444.

25. Kendel, M.; Couzinet-Mossion, A.; Viau, M.; Fleurence, J.; Barnathan, G.; Wielgosz-Collin, G. Seasonal composition of lipids, fatty acids and sterols in the edible red alga Grateloupia turuturu. J. Appl. Phycol. 2013, 25, 425-432.

26. Kelly, G.S. Squalene and its potential clinical uses. Altern. Med. Rev. 1999, 4, 29-36.

27. Das, B. The Science behind Squalene-the Human Antioxidant, 2nd ed.; Toronto Medical Publishing: Toronto, ON, Canada, 2005.

28. Christie, W.W. The Lipid Library. Available online: http://lipidlibrary.aocs.org/index.cfm (accessed on 27 August 2015).

29. Daines, A.M.; Payne, R.J.; Humphries, M.E.; Abell, A.D. The synthesis of naturally occurring vitamin K and vitamin K analogues. Curr. Org. Chem. 2003, 7, 1-15.

30. Netscher, T. Synthesis of Vitamin E. Vitam. Horm. 2007, 76, 155-202. 
31. Gancheva, K.Z.; Dimitrova-Konaklieva, S.D.; Ljubomirov, K.S.; Simeonof, P.S. A comparative study on the sterol composition of some brown algae from the Black Sea. J. Serb. Chem. Soc. 2003, $68,269-275$.

32. Thompson, G.A. Lipids and membrane function in green algae. Biochim. Biophys. Acta 1996, 1302, $7-45$.

33. Parish, E.J.; Honda, H.; Chitrakorn, S.; Livant, P. A facile chemical synthesis of cholest-4-en-3-one. Carbon-13 nuclear magnetic resonance spectral properties of cholest-4-en-3-one and cholest-5-en3-one. Lipids 1991, 26, 675-677.

34. Suzuki, K.; Shimizu, T.; Nakata, T. The cholesterol metabolite cholest-4-en-3-one and its 3-oxo derivatives suppress body weight gain, body fat accumulation and serum lipid concentration in mice. Bioorg. Med. Chem. Lett. 1998, 18, 2133-2138.

35. Patch, C.S.; Tapsell, L.C.; Williams, P.G.; Gordon, M. Plant sterols as dietary adjuvants in the reduction of cardiovascular risk: Theory and evidence. Vasc. Health Risk Manag. 2006, 2, 157-162.

36. Aknin, M.; Moellet-nzaou, R.; Kornprobst, J.M.; Gaydou, E.M.; Samb, A.; Miralleq, J. Sterol composition of twelve Chlorophyceae from the Senegalese coast and their chemotaxonomic significance. Phytochemistry 1992, 31, 4167-4169.

37. Nobuo, M.; Naoko Kyosuke T.; Tamao, Y. Sterol compositions in some green algae and brown algae. Steroids 1968, 12, 41-48.

38. Nasir, M.; Saeidnia, S.; Mashinchian-Moradi, A.; Gohari, A.R. Sterols from the red algae, Gracilaria salicornia and Hypnea flagelliformis, from Persian Gulf. Pharmacogn. Mag. 2011, 7, 97-100.

39. Gressler, V.; Yokoya, N.; Fujii, M.; Colepicolo, P.; Filho, J.; Torres R.; Pinto, E. Lipid, fatty acid, protein, amino acid and ash contents in four Brazilian red algae species. Food. Chem. 2010, 120, 585-590.

40. Sato, S. Effects of environmental factors on the lipid components of Porphyra species. Bull. Jpn. Sot. Sci. Fish. 1975, 41, 326-339.

41. Johns, R.B.; Nichols, P.D.; Perry, G.J. Fatty acid composition of ten marine algae from Australian waters. Phytochemistry 1979, 18, 799-802.

42. Kumari, P.; Reddy, C.R.K.; Jha, B. Comparative evaluation and selection of a method for lipid and fatty acid extraction from macroalgae. Anal. Biochem. 2011, 415, 134-144.

43. Pereira, H.; Barreira, L.; Figueiredo, F.; Custodio, L.; Vizetto-Duarte, C.; Polo, C.; Resek, E.; Engelen, A.; Varela, J. Polyunsaturated fatty acids of marine macroalgae: Potential for nutritional and pharmaceutical applications. Mar. Drugs 2012, 10, 1920-1935.

44. Aknin, M.; Miralles, J.; Kornprobst, M. Sterol and fatty acid distribution in red algae from Senegalese coast. Comp. Biochem. Physiol. B Comp. Biochem. 1990, 96, 559-563.

45. Matanjun, P.; Mohamed, S.; Mustapha, N.M.; Muhammad, K. Nutrient content of tropical edible seaweeds, Eucheuma cottonii, Caulerpa lentillifera and Sargassum polycystum. J. Appl. Phycol. 2009, 21, 75-80.

46. Mozaffarian, D.; Wu, J.H.Y. Omega-3 fatty acids and cardiovascular disease effects on risk factors, molecular pathways, and clinical events. J. Am. Coll. Cardiol. 2011, 58, 2047-2067. 
47. Poudyal, H.; Panchal, S.K.; Ward, L.C.; Brown, L. Effects of ALA, EPA and DHA in high-carbohydrate, high-fat diet-induced metabolic syndrome in rats. J. Nutr. Biochem. 2013, 24, 1041-1052.

48. Gillies, P.J.; Harris, W.S.; Kris-Etherton, P.M. Omega-3 fatty acids in food and pharma: The enabling role of biotechnology. Curr. Atheroscler. Rep. 2011, 13, 467-473.

49. Eckert, G.P.; Lipka, U.; Muller W.E. Omega-3 fatty acids in neurodegenerative diseases: Focus on mitochondria. Prostaglandins Leukot. Essent. Fatty Acids 2013, 88, 105-114.

50. Carballeira, N.M.; Emiliano, A.; Rodriguez, J.; Reyes, E.D. Isolation and characterization of novel 2-hydroxy fatty acids from the phospholipids of the sponge Smenospongia aurea. Lipids 1992, 27, 681-685.

51. Barnathan, G.; Kornprobst, J.M. Sponge fatty acids, 5. Characterization of complete series of 2-hydroxy long-chain fatty acids in phospholipids of two Senegalese marine sponges from the family Suberitidae: Pseudosuberites sp. and Suberites massa. J. Nat. Prod. 1993, 56, 2104-2113.

52. Barnathan, G.; Bourgougnon, N.; Kornprobst, J.M. Methoxy fatty acids isolated from the red alga Schizymenia dubyi. Phytochemistry 1998, 5, 761-765.

53. Kendel, M.; Fleurence, J.; Barnathan, G.; Rabesaotra, V.; Wielgosz-Collin, G. Non-methylene interrupted and hydroxy fatty acids in polar lipids of the alga Grateloupia turuturu over the four seasons. Lipids 2013, 48, 535-545.

54. Matsumoto, G.I.; Shioya, M.; Nagashima, H. Occurrence of 2-hydroxyacids in microalgae. Phytochemistry 1984, 23, 1421-1423.

55. Alugupalli, S.; Portaels, F.; Larsson, L. Systematic study of the 3-hydroxy fatty acid composition of mycobacteria. J. Bacteriol. 1994, 176, 2962-2969.

56. Rezanka, T.; Sokolov, M.Y.; Viden, I. Unusual and very longchain fatty acids in Desulfotomaculum, a sulfate-reducing bacterium. FEMS Microbiol. Ecol. 1990, 73, 231-238.

57. Sjögren, J.; Magnusson, J.; Broberg, A.; Schnuürer J; Kenne, L. Antifungal 3-hydroxy fatty acids from Lactobacillus plantarum MiLAB 14. Appl. Environ. Microbiol. 2003, 69, 7554-7557.

58. Cole, J.J. Interactions between bacteria and algae in aquatic ecosystems. Annu. Rev. Ecol. Evol. Syst. 1982, 13, 291-314.

59. Zabeti, N.; Bonin, P.; Volkman, J.K.; Guasco, S.; Rontani, J.F. Fatty acid composition of bacterial strains associated with living cells of the haptophyte Emiliania huxleyi. Org. Geochem. 2010, 41, 627-636.

60. Nagan, N.; Zoeller, R.A. Plasmalogens: Biosynthesis and functions. Prog. Lipid. Res. 2001, 40, 199-229.

61. Fleury, B.G.; Figueiredo, L.; Marconi, M.I.; Teixeira, V.L.; Ferreira, A.B.B.; Pinto, A.C. Fatty acids as chemotaxonomic markers of marine macrophytes from Rio de Janeiro State, Brazil. Nat. Prod. Commun. 2011, 6, 667-672.

62. Galloway, A.W.E.; Britton-Simmons, K.H.; Duggins, D.O.; Gabrielson, P.W.; Brett, M.T. Fatty acid signatures differentiate marine macrophytes at ordinal and family ranks. J. Phycol. 2012, 48, 956-965.

63. Al-Hasan, R.H.; Hantash, F.M.; Radwan, S.S. Enriching marine macroalgae with eicosatetranoic (arachidonic) and eicosapentaenoic acids by chilling. Appl. Microbiol. Biotechnol. 1991, 35, 530-535. 
64. Hotimchenko, S.V. Fatty acid composition of algae from habitats with varying amounts of illumination. Russ. J. Mar. Biol. 2002, 28, 218-220.

65. Hold, S.L.; Kraan, S. Bioactive compounds in seaweed: Functional food applications and legislation. J. Appl. Phycol. 2011, 23, 543-597.

66. Kaneda, T. Iso- and anteiso-fatty acids in bacteria; biosynthesis, function, and taxonomic significance. Microbiol. Rev. 1991, 55, 288-302.

67. Silva, M.; Vieira, L.M.M.; Almeida, A.P.; Silva, A.M.S.; Seca, A.M.L.; Barreto, M.C.; Neto, A.I.; Pedro, P.; Pinto, E.; Kijjoa, A. Chemical study and biological activity evaluation of two azorean macroalgae: Ulva rigida and Gelidium microdon. Oceanography 2013, 1, 102.

68. Knittelfelder, O.L.; Weberhofer, B.P.; Eichmann, T.O.; Kohlwein, S.D.; Rechberger, G.N. A versatile ultra-high performance LC-MS method for lipid profiling. J. Chromatogr. B Analyt. Technol. Biomed. Life Sci. 2014, 951-952, 119-128.

69. Roussakis, C.; Gratas, C.; Audouin, A.F.; le Boterff, J.; Dabouis, C.; André, M.J.; Moyon, E.; Vo, N.H.; Pradal, G.; Verbist, J.F. Study of in vitro drug sensitivity on a newly established cell line from a primary bronchial epidermoid carcinoma of human origin (NSCLCN6). Anticancer Res. 1991, 11, 2239-2244.

70. Mosmann, T. Rapid colorimetric assay for cellular growth and survival: Application to proliferation and cytotoxicity assays. J. Immunol. Methods 1983, 65, 55-63.

(C) 2015 by the authors; licensee MDPI, Basel, Switzerland. This article is an open access article distributed under the terms and conditions of the Creative Commons Attribution license (http://creativecommons.org/licenses/by/4.0/). 